\title{
Autogenous biological restoration: clinical and social importance
}

\author{
Restauração biológica autógena: importância clínica e social \\ Restauración biológica autógena: importancia clínica y social
}

Received: 11/22/2021 | Reviewed: 11/29/2021 | Accept: 11/30/2021| Published: 12/11/2021

\author{
Moisés Willian Aparecido Gonçalves \\ ORCID: https://orcid.org/0000-0003-3712-5838 \\ Universidade Federal dos Vales do Jequitinhonha e Mucuri, Brazil \\ E-mail: moiseswillian57@gmail.com \\ Vitória Pereira Alves \\ ORCID: https://orcid.org/0000-0002-4919-0509 \\ Universidade Federal dos Vales do Jequitinhonha e Mucuri, Brazil \\ E-mail: vitoriacarbo2013@gmail.com \\ Adriana Maria Botelho \\ ORCID: https://orcid.org/0000-0002-6978-796X \\ Universidade Federal dos Vales do Jequitinhonha e Mucuri, Brazil \\ E-mail: botelhodri@gmail.com \\ Karine Taís Aguiar Tavano \\ ORCID: https://orcid.org/0000-0002-8381-408X \\ Universidade Federal dos Vales do Jequitinhonha e Mucuri, Brazil \\ E-mail: ktavano@gmail.com
}

\begin{abstract}
The Biological Restoration technique aims to use a dental fragment as the main restorative material for the reconstruction of a fractured tooth or with an extensive carious process, which may be autogenous or homogeneous. The objective of this study is to present, through a clinical case, an autogenous biological restoration with 2-year clinical and radiographic monitoring, as an alternative method of restoring teeth with destroyed clinical crown in a 27year-old male patient. The study was approved by the Research Ethics Committee (Number: 4.236.211). On clinical examination, it was found that tooth 16 had a temporary restoration in glass ionomer cement covering an extensive area involving the mesiopalatal cusp and the mesial crest. It was also noted that the patient had a healthy tooth 18 with no chewing function. Thus, it was proposed to make the autogenous biological restoration using tooth 18 extracted from the patient himself. Finally, after 2 years of follow-up, the restoration has good clinical applicability, showing the viability of the technique.
\end{abstract}

Keywords: Permanent dental restoration; Dentistry; Dental public health; Dental esthetic.

\section{Resumo}

A técnica de Restauração Biológica visa utilizar um fragmento dentário como principal material restaurador para a reconstrução de um dente fraturado ou com processo cariado extenso, podendo ser autógeno ou homógeno. O objetivo deste estudo é apresentar, por meio de um caso clínico, uma restauração biológica autógena com acompanhamento clínico e radiográfico de 2 anos, como método alternativo de restauração de dentes com coroa clínica destruída em um paciente de 27 anos do sexo masculino. O estudo foi aprovado pelo Comitê de Ética em Pesquisa da Instituição sob o número: 4.236.211. Ao exame clínico do paciente, constatou-se que o dente 16 apresentava restauração provisória em cimento de ionômero de vidro cobrindo extensa área envolvendo a cúspide mesiopalatina e a crista mesial. Notou-se também que o paciente apresentava o dente 18 hígido, mas sem função mastigatória. Assim, foi proposta a realização da restauração biológica autógena utilizando o dente 18 extraído do próprio paciente. Por fim, após 2 anos de seguimento, a restauração apresenta boa aplicabilidade clínica, demonstrando a viabilidade da técnica.

Palavras-chave: Restauração dentária permanente; Odontologia; Saúde pública; Estética dentária.

\section{Resumen}

La técnica de Restauración Biológica tiene como objetivo utilizar un fragmento de diente como principal material restaurador para la reconstrucción de un diente fracturado o con un proceso de caries extenso, que puede ser autógeno o homogéneo. El objetivo de este estudio es presentar, mediante de un caso clínico, una restauración biológica autógena con un seguimiento clínico y radiográfico de 2 años, como método alternativo de restauración de dientes con corona clínica destruida en un paciente de 27 años, masculino. El estudio fue aprobado por el Comité de Ética en Investigación de la Institución con el número: 4.236.211. Tras el examen clínico del paciente, se encontró que el diente 16 tenía una restauración provisional en cemento de ionómero de vidrio que cubría un área grande que involucraba la cúspide mesiopalatina y la cresta mesial. También se observó que el paciente tenía un diente 18 sano, pero sin función masticatoria. Así, se propuso realizar una restauración biológica autógena utilizando el diente 18 
extraído del paciente. Finalmente, tras 2 años de seguimiento, la restauración tiene una buena aplicabilidad clínica, demostrando la viabilidad de la técnica.

Palabras clave: Restauración dental permanente; Odontología; Salud pública dental; Estética dental.

\section{Introduction}

The Biological Restoration technique aims to use a dental fragment as the main restorative material for reconstructing a tooth that's fractured or has an extensive carious process. Such technique is homogeneous, when the tooth used to obtain the fragment is donated from a Bank of Human Teeth, or autogenous, when this tooth is extracted from the own patient (Tavano et al., 2009; Alcântara et al., 2010).

Chosack and Eidelman began studies in 1964 using natural dental fragments to restore fractured teeth (Chosack \& Eidelman, 1964). But, only with the studies by Santos and Bianchi, in 1991, that the name of the technique as Biological Restoration was recommended (Santos \& Bianchi, 1991), being initially used in anterior deciduous teeth (Santos \& Bianchi, 1991; Wadhwani et al., 2013; Alcântara et al., 2011).

A multitude of materials are used in dentistry to reconstruct dental losses: amalgam, composite resin, ceramics, metals, glass ionomer cements, among others (Reis \& Lourguercio, 2004). However, no restorative material has properties superior to dental tissues (Wadhwani et al., 2013; Rao et al., 2020). Thus, the use of dental fragments as a restorative medium proved to be a great resource for dental restorations, presenting as advantages, excellent biocompatibility, in addition to preserving the contour, colors, luster, shape, texture, surface smoothness and natural physiological wear (Alcântara et al., 2011; Singhania \& Pandey, 2016; Singh et al., 2020), and also, the report of the patient's satisfaction in having his/her tooth restored in a natural way (Tavano et al., 2009). However, disadvantages are also reported in the literature, which are based on the difficulty in obtaining an extracted tooth similar to the element that will be reconstituted, in terms of color, shape and size. Another possibility is the difficulty of acceptance that can happen on the part of the patient, especially when it comes to homogeneous restorations (Busato et al., 1998; Md et al., 2014).

Although it presents disadvantages or limitations, like any other restorative technique, the use of biological restorations consists of an alternative procedure to the use of conventional means, with very relevant clinical and social success (Baratieri et al., 1998; Corrêa-Faria et al., 2010).

Thus, this case report aims to describe an uncommon clinical case, in which an autogenous biological restoration was performed to recover the esthetics and functionality of a fractured dental element, with clinical and radiographic follow-up from a period of 2 years.

\section{Methodology}

This is a descriptive study in the form of a clinical case report, using data from a patient's medical record together with his photographs and image exams. The methodology followed for the study was described by Menezes-Silva et al, 2018 . All procedures carried out in studies involving human participants were in accordance with the ethical standards of the institution and/or national research committee and with the Helsinki Declaration of 1964 and its subsequent amendments or comparable ethical standards. The study was approved by the Research Ethics Committee (Number: 4.236.211).

\section{Case Report}

A 27-year-old male patient went to the Dentistry Clinic, reporting that he had a tooth missing a restoration and had painful symptoms. Due to the painful process, the patient had previously sought a dentist to solve his problem. Thus, on clinical examination it was observed that element 16 presented a temporary restoration in glass ionomer cement covering an 
extensive area of tooth loss involving the mesiopalatal cusp and mesial marginal ridge. Interproximal radiography of tooth 16 was performed to verify the extent of the existing restoration (Figure $1 \mathrm{~A}$ ).

Figure 1: A - Initial radiographic image; B - Clinical aspect of glass ionomer cement restoration on tooth 16 and tooth 18 extraction area.



Source: Authors.

At first, it was proposed to the patient to perform a cast metal restorations or ceramic restoration as a way to reestablish the clinical crown. However, due to the fact that it would be necessary to wear healthy cusps in order to perform an indirect restoration, and because of the need for financial investment that did not match the patient's condition, the preparation of an autogenous biological restoration was planned. The autogenous biological restoration would be performed with a fragment of tooth 18 that was healthy, but without function because it did not have the antagonist tooth, which indicated its removal. With the patient's acceptance for the proposed treatment, the advantages and disadvantages of the technique were presented and the official consent was obtained to perform the procedures.

Thus, tooth 18 was initially extracted (Figure 1B), which had a similar size, shape and color to the tooth to be restored. This tooth was sterilized at $121^{\circ} \mathrm{C}$ for 15 minutes, following the pre-established biosafety parameters (Hossain et al., 2012), and then stored in saline so that it did not lose its brightness and color characteristics.

In the next session, a pulp vitality test was performed and the tooth responded positively. The preparation of element 16 was performed allowing the fragment to have at least $2.5 \mathrm{~mm}$ thickness in enamel and dentin throughout its length. The preparation had shoulder finish line with rounded internal angles (Figure 2A). Molding was performed using condensation silicone (Perfil, Coltene or Vigodent S/A Indústria e Comércio, Rio de Janeiro, RJ, Brazil) for further confection of the models using type IV plaster (Dentsply, Petrópolis, RJ, Brazil) to be set up in an articulator. A provisional restoration in acrylic resin (Dencrilay Pó, Dencril, Santo André, SP, Brazil) was made to maintain tooth stability in the arch and promote protection and function of the element 16 until the final restoration was performed (Figure 2B). 
Figure 2: A - Preparation of the coronary remnant of tooth 16; B - Temporary restoration in acrylic resin.

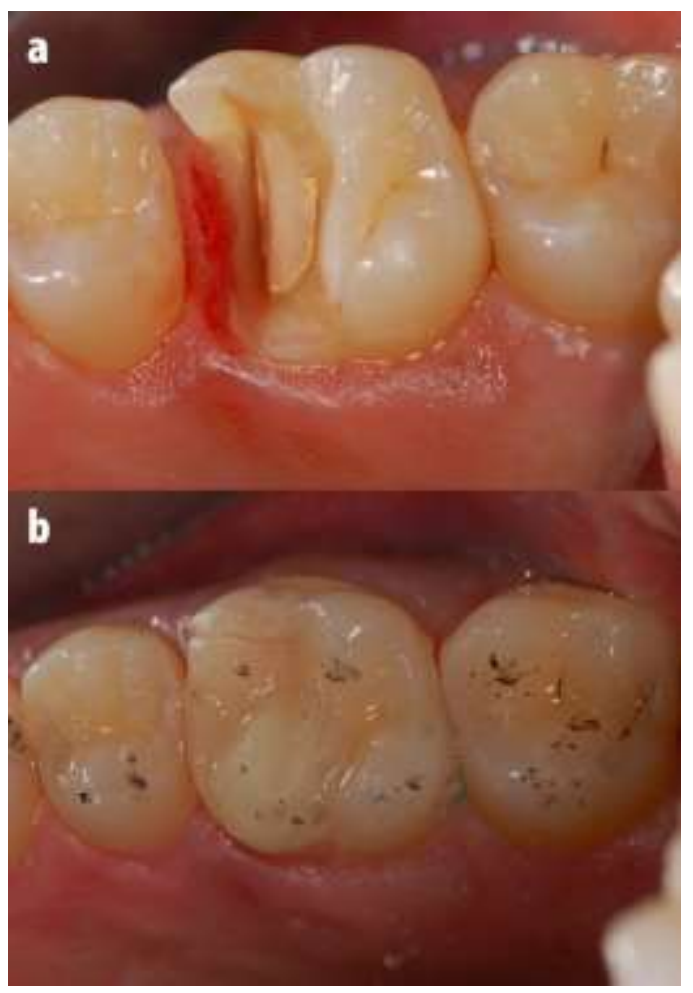

Source: Authors.

The laboratory steps for the cutting of the autogenous fragment were firstly the separation of tooth 18 in a coronal portion, for cutting the fragment, and in a root portion, which was stored for other purposes, including confectioning biological pins (Alcântara et al., 2010; Tavano et al., 2020) (Figure 3A). For cutting the fragment, diamond tips were used, in high rotation, under intense refrigeration. The fragment was obtained in order to adapt appropriately to the plaster model previously made. To adapt the fragment to the dental remnant, a refill in composite resin in the fragment color (Filtek Z-350 XT, 3M ESPE, Sumaré, SP, Brazil), was performed after conditioning with $37 \%$ phosphoric acid (Dentalville, Joinville-SC, Brazil) for 30 seconds in enamel and 15 seconds in dentin, and subsequent washing, drying and application of adhesive system (Adper Single Bond 2, 3M ESPE, Sumaré, SP, Brazil) so that there was a correct marginal seal (Figure 3-B, C and D). A previous occlusal check was performed on the plaster model to facilitate the adjustment clinically. 
Figure 3: A - Separation of the coronal and root portions of tooth 18; B - Fragment cut and adapted in plaster die; C, D Adaptation of the fragment in plaster die after marginal relining with composite resin.



Source: Authors.

Afterwards, the fragment was tested on the dental remnant and radiographed (Figure 4 - A and B).

Figure 4: A - Adaptation of the fragment to the dental remnant 16; B - Radiographic aspect of the fragment adapted to the dental remnant.

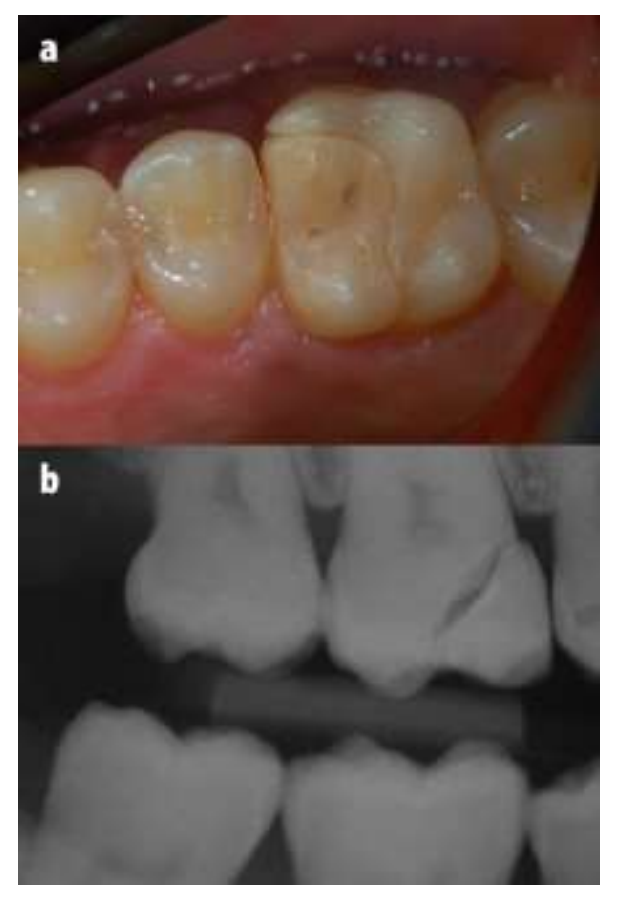

Source: Authors.

Due to the presence of blackened grooves along its occlusal surface, these were sealed using sealant (DefenseChroma, Angelus, Londrina, PR, Brazil) to avoid the possibility of development of cavities in the future. The cementation sequence was carried out by conditioning the enamel surfaces of the preparation and the fragment with $37 \%$ phosphoric acid for 15 seconds followed by washing and drying. The fragment was then cemented to the dental remnant using self-adhesive cement (RelyX Adhesive U200, 3M ESPE, Sumaré, SP, Brazil). Excess cement was removed using an explorer probe and 
dental floss. After these steps, light curing was performed for 60 seconds on each dental surface. An interproximal radiography was performed to confirm the success of the cementation (Figure 5-A and B). The occlusion was checked and oral hygiene guidelines were recommended to the patient.

Figure 5: A and B - Clinical and radiographic images after cementation of the fragment, respectively.

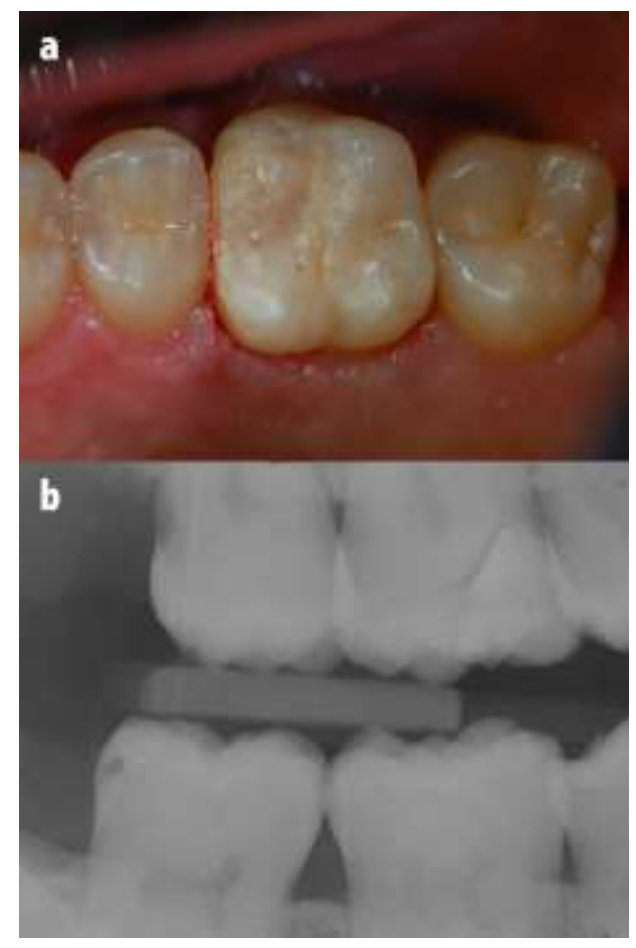

Source: Authors.

After a 2-year follow-up, a fracture was observed in the mesial margin of the restoration, in the region corresponding to the composite resin used for marginal relining. Thus, a vertical slot restoration was performed for its repair at the fracture site with A3 composite resin (Filtek Z-350 XT, 3M ESPE, Sumaré, SP, Brazil) (Figure 6).

Figure 6: Confection of a vertical composite resin slot as a way to repair biological restoration (A and B).

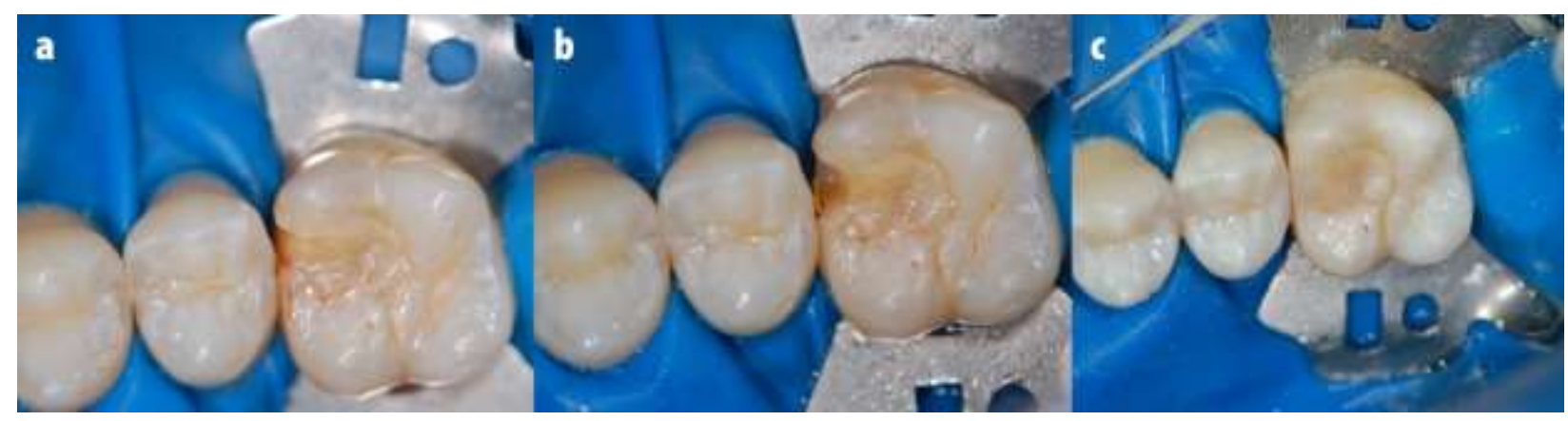

Source: Authors.

Finally, even after a 2-year follow-up, despite a fracture in one of the fragments' surfaces, which was possible to repair, it is clear that the biological restoration showed a good clinical performance, giving back the function and a natural esthetic (Figure 7). 
Figure 7: A - Radiographic image after 2 years of clinical follow-up; B - Clinical aspect after 2 years of clinical follow-up.

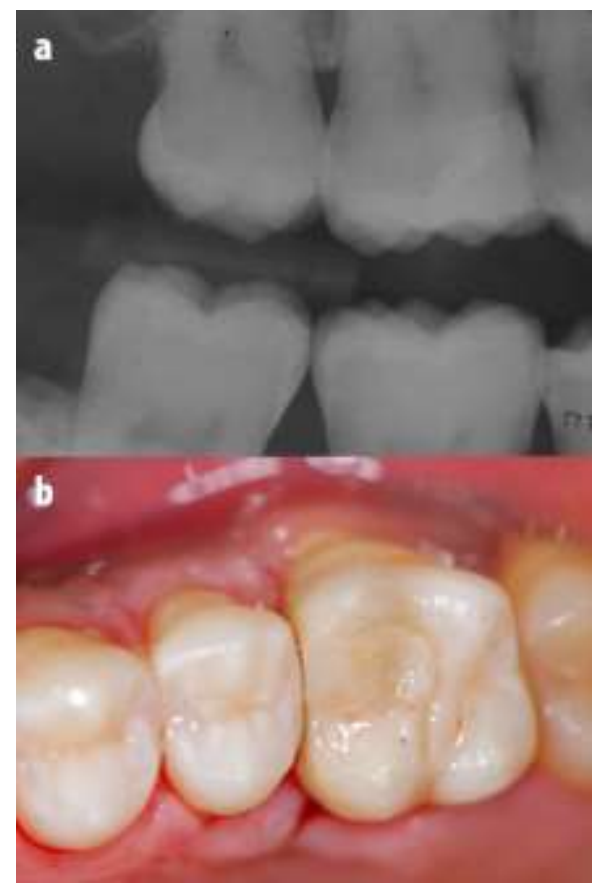

Source: Authors.

\section{Discussion}

The use of biological fragments for the reconstruction of teeth with extensive coronary destruction is an extremely viable and efficient way, promoting the return of function and esthetics similar to natural dental elements (Sanches et al., 2007; Grewal \& Seth, 2008; Alcântara et al., 2011; Carvalho et al., 2020). In teaching centers, the technique is low-cost, making a great social and emotional contribution for low-income patients (Corrêa-Faria et al., 2010).

An important point to note is that when there is a fracture-like failure in the fragment, the use of direct restorations is sufficient to restore function and esthetics, as occurred. Contrarily, in the case of indirect restoration, total replacement would be the most suitable treatment. Thus, biological restorations have the advantage of being repaired with composite resins, consequently avoiding higher costs for the patient. In this case, after 2 years, there was a fracture of the margin, in the portion where relining in resin is performed to supply the deficiency of the manual cut. Such fracture may have been caused by some premature point still present in the restoration, or even by inadequate functional or eating habits of the patient, and was resolved with direct resin restoration. According to the patients' reports, regarding the emotional aspect, the use of this technique promotes a feeling of having their teeth back intact (Pegoraro et al., 2006; Tavano et al., 2009).

Even with such clinical success, highly satisfactory esthetic results and great social applicability, biological restorations do not replace the use of conventional restorative techniques, being considered alternative techniques to be used considering the peculiarities for each particular case (Pegoraro et al., 2006; Tavano et al., 2009).

It is important to note that because it is a natural tooth, biological restorations are liable to undergo remineralization and demineralization, being susceptible to the development of cavities, therefore, it is important to have adequate oral hygiene care to minimize this risk (Menezes-Silva et al., 2018).

Among the limitations of using this technique is the difficulty in selecting a tooth compatible with the size, color and shape of the tooth to be restored, especially when it comes to homogeneous fragments. On the other hand, when the restoration is autogenous, acceptance is immediate and the physical characteristics of the dental element favor bonding. 
Finally, biological restorations have good clinical applicability, resistance, durability and esthetics, but further studies are needed to elucidate the longevity of these restorations, since few studies are found in the literature on the subject.

\section{Conclusion}

The use of an autogenous fragment as a means of restoring extensively destroyed teeth, promotes good clinical performance, returning esthetics and function to the restored tooth, as well as greater acceptance by the patient. In addition, it is a positive financial factor and is of great social and emotional contribution for low-income patients. Furthermore, more clinical studies are needed to elucidate the longevity of biological restorations.

\section{Acknowledgments}

The authors would like to thank the patient for his collaboration during dental treatment and for the consent to publish this work. We would also like to thank the Universidade Federal dos Vales do Jequitinhonha e Mucuri, Programa de PósGraduação em Odontologia (PPGOdonto) and the Fundação de Amparo à Pesquisa do Estado de Minas Gerais (FAPEMIG) for providing all the support for this study to be conducted.

\section{References}

Albuquerque, N. L. G., Mendonça, J. S., Fonteles, C. S. R., Pereira, J. C., \& Santiago, S. L. (2015). Biological restorations as an alternative to reconstructing posterior teeth: A case report. Oper Dent, 40:123-128.

Alcântara, C. E. P., Corrêa-Faria, P., Tavano, K. T. A., \& Botelho, A. M. (2011). Fragment reattachment associated with pulpotomy in a posterior tooth with incomplete root formation. Eur J Prosthodont Restor Dent, 19(4):155-159.

Alcântara, C. E. P., Corrêa-Faria, P., Vasconcellos, W. A., \& Ramos-Jorge, M. L. (2010). Combined technique with dentin post reinforcement and original fragment reattachment for the esthetic recovery of a fractured anterior tooth: a case report. Dent Traumatol, 26(5):447-450.

Baratieri, L. N., Ritter, A. V., Monteiro, J. S., \& Mello Filho, J. C. (1998). Tooth fragment reattachment: an alternative for restoration of fractured anterior teeth. Pract Periodonts Aesthet Dent, 10:115-125.

Busato, A. L., Loguercio, A. D., Barbosa, A. N., Sanseverino, M. C., Macedo, R. P., \& Baldissera, R. A. (1998). Biological restorations using tooth fragments. Am J Dent, 11:46-49.

Carvalho, G. A. O., Ribeiro, A. O. P., Câmara, J. V. F., \& Pierote, J. J. A. (2020) Dental fragment bonding as a technique in oral rehabilitation: literature review. Research, Society and Development, 9(7): e667974567.

Chosak, A., \& Eidelman, E. (1964). Rehabilitation of a fractured incisor using patient's natural crown: a case report. J Dent Child, $31: 19-21$.

Corrêa-Faria, P., Alcântara, C. E., Caldas-Diniz, M. V., Botelho, A. M., \& Tavano, K. T. (2010). "Biological restoration": Root canal and coronal reconstruction. J Esthet Restor Dent, 22:168-177.

Grewal, N., \& Seth, R. (2008). Comparative in vivo evaluation of restoring severely mutilated primary anterior teeth with biological post and crown preparation and reinforced composite restoration. J Indian Soc Pedod Prev Dent, 26(4):141-148.

Hossain, M. S., Balakrishnan, V., Rahman, N. N., Sarker, M. Z., \& Kadir, M. O. (2012). Treatment of clinical solid waste using a steam autoclave as a possible alternative technology to incineration. Int J Environ Res Public Health, (3):855-867.

Md, I., Singh, D. K., Nandlal, B., Kumar, P. P., \& Singh, D. R. (2014). Biological restoration in pediatric dentistry: a brief insight. Int J Clin Pediatr Dent, 7(3):197-201.

Menezes-Silva, R., Botelho, L. P., Botelho, A. M., \& Tavano, K. T. A. (2018). Biological restoration in permanent tooth: four-year follow-up. Braz, Dent Sci, 21(1): 126-132.

Pegoraro, C. N., Domingues, L. A., \& Trassi, P. M. M. M. (2006). Biological onlay: An alternative technique for restoration of severely damaged posterior tooth. A case report. Rev Dent Press Estét, 3:114-115.

Rao, D. G., Havale, R., Karobari, N. M., Latha, A. M., Nagaraj, M., Tharay, N., et al. (2020). Acceptance or rejection of biological restoration: An educational interventional study. J Family Med Prim Care, 9:1170-1176.

Reis, A., \& Lourguercio, A. D. Tooth fragment reattachment current treatment concepst. (2004). Pract Period Aesthet Dent, 16:739-740.

Sanches, K., de Carvalho, F. K., Nelson-Filho, P., Assed, S., Silva, F. W., \& Queiroz, A. M. (2007). Biological restorations as a treatment option for primary molars with extensive coronal destruction - Report of two cases. Braz Dent J, 18:248-252. 
Research, Society and Development, v. 10, n. 16, e213101623718, 2021

(CC BY 4.0) | ISSN 2525-3409 | DOI: http://dx.doi.org/10.33448/rsd-v10i16.23718

Santos, J. F. F., \& Bianchi, J. (1991). Restoration of severely damaged teeth with resin bonding systems: case reports. Quintessence Int, 22(8):611-615.

Singh, P., Srivastava, N., Rana, V., Kaushik, N. (2020). Clinical Evaluation of Restoration of Grossly Carious Primary Teeth Using Biological Approach. Int J Clin Pediatr Dent, 13(1): S55-S63.

Singhania, H., \& Pandey, V. (2016). Biological restoration in dentistry- A review. Int J Res Health Allied Sci, 2:11-12.

Tavano, K. T. A., Botelho, A. M., Motta, T. P., \& Paes, T. M. O. (2009). 'Biological restoration': total crown anterior. Dent Traumatol, 25(5):535-540.

Tavano, K. T. A., Botelho, A. M., Douglas-de-Oliveira, D. W., Avila, A. F., \& Huebner, R. (2020) Resistance to fracture of intraradicular posts made of biological materials. BMC Oral Health, 3;20(1):300.

Wadhwani, K. K., Hasija, M., Meena, B., Wadhwa, D., \& Yadav, R. (2013). Biological restorations: Option of reincarnation for severely mutilated teeth. European J Gen Dent, 2(1):62-66. 